\title{
Setkání římského práva s právem staré Číny
}

\author{
Michal Tomášek
}

Právnická fakulta, Univerzita Karlova

Kontaktni e-mail: tomasekm@prf.cuni.cz

\section{Contacts Between Roman Law and Ancient Chinese Law}

\begin{abstract}
:
Two big ancient civilizations - Roman and Chinese - created important legal systems which were to influence legal development in Europe and in China respectively. Archeologic discoveries prove there has been exchange of goods between both empires. China was exporting silk to Rome, Romans were exporting glass to China. In 2nd century BC, Han dynasty emperor opened a commercial route later named "Silk road". Chinese were protecting their exports by military convoys applying their legal regulations. On some spots, they transmitted their goods to intermediators who were dealing with Roman merchants. Romans were using their ius gentium. For maritime trade Chinese opened ports under state surveillance in today's Vietnam. There are no proofs that Chinese were interested in Roman law and vice versa. Although Romans were visiting Han dynasty court no official Chinese envoy has ever visited Roman officials.
\end{abstract}

Keywords: Roman law; ancient Chinese law; Silk road; ius gentium; Lex Rhodia de iactu

Klíčová slova: římské právo; starověké čínské právo; Hedvábná cesta; ius gentium; Lex Rhodia de iactu

DOI: $10.14712 / 2464689 X .2020 .2$

Financování: Tato stat' vznikla v rámci výzkumného programu Univerzity Karlovy Progres Q02 „Publicizace práva v evropském a mezinárodním srovnání“, Univerzitního výzkumného centra UNCE/HUM/028 „Pražské centrum pro výzkum míru“ a jako výstup profilového oboru výzkumu na Univerzitě Karlově „Právní systémy Dálného východu a evropské právo“.

Autor děkuje profesoru Michalu Skřejpkovi za cenné rady a připomínky k římskoprávním pasážím. 
V roce 2013 vyhlásil čínský prezident Si Ťin-pching iniciativu „Pás a cesta“ (一带一路). ${ }^{1}$ Projekt názvem částečně navazuje na dávnou Hedvábnou cestu, po níž probíhal obchod mezi čínskou říší, Mezopotámií, Persií, Indií a Itálií. V nové podobě má být obchodní tepna nejen modernizována, ale také rozšířena o námořní dimenzi v Asii, Evropě a Africe. O právním rámci nové Hedvábné cesty toho zatím mnoho nevíme. ${ }^{2}$ Protože Č́ínané rádi spojují své historické úspěchy se současným ekonomickým boomem a dávají na odiv př́islušné paralely, je dobré se podívat do začátků obchodních styků Č́iňanů s Evropany a hledat tam odpovědi i na to, co dosud nevíme o budoucnosti.

\section{Právo římské a právo čínské}

V době vrcholného rozkvětu římského práva byl v Číně vybudován kompaktní právní systém, který lze jeho významem pro další vývoj čínského práva srovnat s evropským významem římského práva, jež se zhruba $\mathrm{v}$ téže době formovalo desetitisíce kilometrů na západ. Římské právo představovalo odkaz právního systému státu, který zanikl, resp. pokračoval Východořímskou říší, a jeho právní systém přebíraly v různých variantách nově se formující státy na území dřívější Západořímské říše. Klasické čínské právo bylo právem státu, který nezanikl a jehož kontinuita pokračovala dále. Zdánlivě byla kontinuita klasického čínského práva s právem současným přerušena po pádu čínského císařství v roce 1911. Ovšem četné př́íklady z pozdější interpretační praxe svědčí o tom, že staré čínské právo není zdaleka mrtvo. Oba právní systémy, totiž právní systém čínský a právní systém římský, si byly v lecčems podobny, ale přesto mezi nimi panovaly značné rozdíly. Už od dob nejstarších byly v obou kulturách právní vztahy mezi lidmi ovládány obyčeji, v Číně $l i$ (礼), v Římě mos maiorum. Kromě toho znali Římané ještě zvláštní kategorii pravidel, zvanou fas, tzv. právo božské, normy, které měly náboženský charakter. Tuto kategorii staří Číňané neměli, protože veškerý soubor li považovali za odraz vůle nebes, a tedy za přirozený pořádek věcí. Jeho porušení sankcionovali tresty sing (刑), a proto byl pojem právo ve staré čínštině ztotožňován s tímto pojmem a rozumělo se jím právo trestní. Pojem právo $f a$ (法), obdoba římského ius, byl v Č́ně zaveden v souvislosti s vystoupením školy legistů ve 4. století př. Kr. Označoval soubor právních norem, čili psané právo, v čemž se podobal římskému ius. Na rozdíl od římského ius, které mělo souborně upravovat vztahy mezi lidmi, upravovaly v Č́ně tyto vztahy i nadále obyčeje $l i$, jejichž zachování a upevňování podporovala doktrína konfuciánství. Protiklad mezi právními pravidly $f a$ a obyčeji li odráží tisíciletý rozpor mezi legismem a konfuciánstvím, který nebyl v mnohém dodnes překonán. ${ }^{3}$ Právo bylo v Č́ně chápáno toliko ve smyslu penálním a právní vztah mohl vzniknout jen za předpokladu, že byla porušena morální norma. Takové chápání práva mělo ovšem vliv na vztah mezi morálkou a právem. Morální hledisko bylo hlavní, protože právní hledisko se odvozovalo pouze z něj. Nemohlo tedy, alespoň teoreticky, existovat právo, které by bylo v rozporu s morálkou, zatímco morálka se mohla účinně uplatnit i bez

\footnotetext{
1 V naší, zejména publicistické, literatuře je název tohoto projektu překládán jako „Pás a stezka“. Autor této stati vychází z odborné sinologické literatury, která př́slušný historický pojem, na nějž současná čínská iniciativa navazuje, označuje „Hedvábná cesta“. Sama čínština používá slovo 路 - cesta, jehož překlad se odráží i v anglickém názvu „Belt and road“.

2 K diskusi nad těmito otázkami viz např. TOMÁŠEK, M. Fórum o právní spolupráci v projektu „Pás a cesta“. Peking, 2. a 3. července 2018. Právník, 2018, č. 10.

3 TOMÁS̆EK, M. Právní systémy Dálného východu I. Praha: Karolinum, 2016.
} 
prostřednictví práva. Ovšem po vzniku práva, které mělo dodržování morálních norem chránit, ztratil každý obyčej výlučně morální charakter, protože v sobě implikoval hrozící právní odpovědnost.

Pragmatičtí Římané zušlecht'ovali regulaci vztahů mezi lidmi rozvojem práva ius, které členili na právo civilní (ius civile), právo úřednické (ius honorarium) a na právo (jiných) národů (ius gentium). ${ }^{4}$ Oblasti rímského práva civilního odpovídaly rozsahem a obsahem čínské obyčeje li. Pokrývaly všechny vztahy, které si lze z hlediska soukromého práva představit. Určitou zajímavostí je, že staročínské právo nerozlišovalo mezi kategoriemi, které my nazýváme práva věcná a práva závazková. Významné místo tu zaujímaly i obyčeje obchodní, které popisují i někteří římští autoři. Římskému úřednickému právu zhruba odpovídaly staročínské úrurední akty ming (命). Velmi rozvinutý byl staročínský systém psaného trestního práva hmotného i procesního. Naopak Č́ńané, na rozdíl od Rímanů, nerozvíjeli civilní proces v duchu Konfuciova učení, že soudit se o právo je nemravné a odporuje přirozenému pořádku věcí. Římskému ius gentium neodpovídala žádná součást staročínského práva. Cizinci (barbaři) se v té době vykytovali v Č́ně velmi sporadicky. Byli sice fyziologicky snadno odlišitelní, ale bralo se, že se musejí přizpůsobit tamním zvyklostem. Zvláštní pravidla pro cizince byla v Č́ně přijata až daleko později.

Na pozadí novější klasické právní vědy, která začala rozlišovat právo soukromé (ius privatum) a právo veřejné (ius publicum), by se rozdíl mezi čínským a římským právem dal formulovat tak, že oblast práva soukromého byla v Číně upravena obyčeji, kdežto oblast práva veřejného právem psaným. Odtud také charakteristika staročínského práva jako práva smíšeného, které se opíralo o triádu pramenů, totiž o obyčeje, psané normy a soudní precedenty. K tomuto srovnání budiž ovšem dodány dvě vysvětlivky. Zaprvé, v římském právu soukromém stáli vůči sobě jednotlivci naroveň, což v čínských obyčejích neplatilo, nebot' se tam naopak uplatňovala konfuciánská hierarchie výše a níže postavených osob. Naopak pojetí římského ius publicum, kde stát vystupoval jako nositel veřejné moci, se shoduje s čínským pojetím pojmu právo fa. Zadruhé čínská právní nauka nikdy neznala pojmy soukromé a veřejné právo a nepoužívá je dodnes. Teoreticky zajímavým se jeví postavení staročínských obchodních obyčejů. Obecně by mohly patřit do soukromé sféry, ale jelikož už od dob nejstarších nad obchodováním v Č́ině vždy dozíral úředník, je tu př́tomen výrazný veřejnoprávní prvek.

\section{Kontakty mocných říśí}

Jaký byl vzájemný vztah tehdejších velkých právních systémů, totiž práva čínského a práva ř́mského? Setkaly se vưbec, měly možnost vzájemně se poznat, či dokonce ovlivnit? Spekulaci o jejich vzájemném setkání může posílit prokazatelná výměna zboží, a tedy i obchodní kontakty mezi oběma říšemi: Římskou říší a její čínskou protiváhou, říší dynastie Chan. ${ }^{5}$ Ve starověkém Římě prosluli Č́ínané především díky hedvábí. Čínský název hedvábí $s$ ' (丝) ovlivnil jeho latinské označení sericus. Odtud se odvozuje latinský název Číny jako Serica a Číňanů jako Seres. Spisovatel Plinius Starší (Plinius Secundus) ve svém díle Naturalis historia (Př́rodověda) z roku 77 po Kr. píše, že mezi horou Tabisem

\footnotetext{
4 SKŘEJPEK, M. Lex et ius. Zákony a právo antického Řima. Plzeň: Vydavatelství a nakladatelství Aleš Čeněk, 2018.

5 Dynastie Chan vládla v Č́ně od roku 206 př. Kr. do roku 220 po Kr.
} 
a Východním mořem ,žijí Sérové, známí hedvábím, jež roste v lesích...“.6 Pro pořádek budiž ovšem dodáno, že v rrímských pramenech nacházíme o pravděpodobných Č́ínanech také zmínku jako o Sinae, podle mocné dynastie Čchin (秦), ${ }^{7}$ konkrétně v pramenech o setkání s těmito obyvateli námořními cestami. ${ }^{8}$ Není ovšem zcela jisté, zda se římské označení Seres zcela kryje s etnikem, které se v době Chanské říše vyprofilovalo jako Chanové, čili praví a etničtí Č́ńnané. Dějepisci a cestopisci toto etnikum zřetelně spojují s hedvábím. Jsou popisováni jako civilizovaní lidé, mírné, spravedlivé a skromné povahy, kteří se nechtějí zbavovat svých zvyků, ale také svých výrobků, mezi nimiž na prvním místě stojí hedvábí. ${ }^{9}$

Také Č́ínanům nebyla existence Římské ř́íše neznámá. Nazývali ji Ta Čchin (大秦) a soudě dle Dějin Chanů (汉书 Chan-šu), které sepsali historik Pan Ku se svojí sestrou Pan Čao, považovali Č́ńnané Ř́many za svůj geograficky velmi vzdálený protiklad. Odtud také znak 秦 shodný s označením bývalé čínské dynastie. Znak 大 naznačoval, že Římskou říši považovali Číňané za „velmoc“. Čínské označení Římské říše dokresluje Fan Yüe
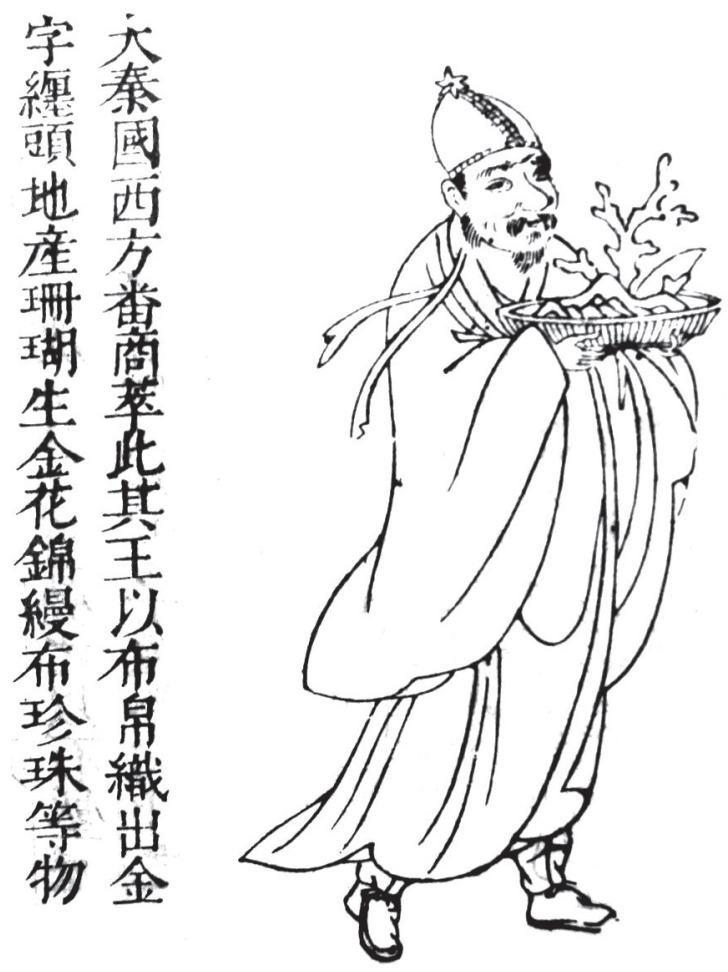

Říman ve staročínských představách

Plin. NH, VI, 54.

Dynastie Čchin vládla v Č́ně od roku 221 do roku 206 př. Kr.

LIŠČÁK, V. Čína - Dobrodružství Hedvábné cesty. Po stopách styků Východ-Západ. Praha: Set Out, 2000.

9 YULE, H. Cathay and the way thither, being a collection of mediaeval notices of China. Vol. I a II. London: Hakluyt Society, 1866. 
v Dějinách pozdních Chanů (后汉书 Chou Chan-šu), podle něhož jsou Římané lidé vysocí a souměrní, připomínají Č́ńnany, a proto lze jejich zemi nazývat Ta Čchin. ${ }^{10}$ Král není podle Letopisů stálý, ale je vybírán a těší se velké vážnosti. V zemi je mnoho pokladů jako zlato, stř́bro a drahé kameny a vyrábějí se tam pozoruhodné a barevné tkaniny. Archeologické nálezy dokládají, že v téže době se do Číny dostává ze západu římské sklo, které Číňané někdy brali jako náhradu nefritu. Obchodování s římským sklem zaznamenávají i Letopisy pozdních Chanů, které zmiňují sklo jako produkt z ř́šse Ta Čchin, nebo synonymně Li-t’ien (犁靬). Římské sklo se mohlo dostávat do Číny též námořními cestami, a to přes Vietnam, tehdy kontrolovaný Chanskou říší. V okolí dnešního Ho Či Minova města byly nalezeny římské mince a skleněné předměty. ${ }^{11}$

Kontakty obou mocností komplikovala nejen velká vzdálenost, ale i mocná Parthská říše, která se mezi nimi rozkládala. Rímané s ní měli četné vojenské konflikty a Číňanům později bránila v přímém obchodování s Římskou říší. Zájem poznat „západní“ kraje zesílil v Č́íně za panování chanského císaře Wu-tiho v letech 140-87 př. Kr., jehož říše sahala od severní Koreje až po střední Asii. Jeho heslem bylo „obrana a obchod“. Je považován za zakladatele Hedvábné cesty a za iniciátora čínských expedic na západ. Nejznámější byla v tomto ohledu mise vyslance Čchang Čchiena, který mohl roku 125 př̀. Kr. potvrdit císaři, že na západě existují vyspělé civilizace, s nimiž stojí za to obchodovat. Až do Ř́mské ř́rše se pochopitelně nedostal, stejně jako jeho následovník Kan Jing o sto let později. Ten doputoval asi Římanům nejblíže, ale další cestu mu „,rozmluvili“ Parthové, protože si chtěli udržet monopol obchodovat s čínským hedvábím. ${ }^{12}$ Podle Dějin pozdních Chanů měl roku 166 po Kr. k císařskému dvoru doputovat „vyslanec krále An-tuna“ (zřejmě Marka Aurelia Augusta), který s sebou přivezl dary ze slonoviny, nosorožčích rohů nebo želvoviny. Těmi ovšem Římané Číňany nijak neoslnili. ${ }^{13}$ Je možné, že původní rímské zboží bylo Ř́manům po cestě uloupeno a že dary pro římského císaře získali v jižní Asii. ${ }^{14}$ Někteří historici se domnívají, že tito Římané nebyli ve skutečnosti vyslanci, ale obchodníci. Ostatně, hranice mezi diplomacií a obchodem byla v čínsko-římských vztazích často neznatelná. ${ }^{15}$

\section{Obchodní kontakty}

Dnes víme, že starověcí Číňané měli rozvinutý systém obyčejů, které jim nahrazovaly to, co Římané vyvinuli jako právo. Obchodní obyčeje staré Č́ny známe z tamních pramenů, ale ve své době se o ně Číňané zřejmě nechtěli s nikým dělit, natož aby se se jich zbavovali. Již zmíněný Plinius píše, že Sérové zanechávali zboží na prodej na opačném břehu řeky. Pokud se domnívali, že k obchodu s ním nedošlo, vyzvedli si je zpět. ${ }^{16}$ Rovněž tak ř́mský geograf Pomponius Mela v díle De chorographia (O popisu krajin) v roce 43 po Kr. charakterizuje Séry jako „,velmi spravedlivý národ, proslulý svým způsobem obcho-

\footnotetext{
10 HULSEWÉ, A. F. P. China in Central Asia. The Early Stage: 125 B.C.-A.D. 23. Leiden: E. J. Brill, 1979.

11 CRESPIGNY, R. de. A Biographical Dictionary of Later Han to the Three Kingdoms (23-220 AD). Leiden: Koninklijke Brill, 2007.

12 HILL, J. E. Through the Jade Gate to Rome: A Study of the Silk Routes during the Later Han Dynasty, First to Second Centuries CE. Washington: BookSurge, 2009.

13 HULSEWÉ, $c$. $d$.

14 YULE, $c . d$.

15 CRESPIGNY, $c . d$.

16 Plin. NH, VI, 54.
} 
du, který probíhá za jejich nepřítomnosti, poté co zanechají své zboží na dohodnutém místě..." 17 Číňané tedy do přímého obchodního kontaktu s Římany nepřicházeli. Proto Rímané vnímali čínské obchodní obyčeje tak, jak je popisuje Pomponius. Číňané se se svým zbožím neodvažovali dále než na okraj pouště Taklamakan v dnešním Ujgursku a obchod s Ř́many tak za ně obstarávali Řekové nebo Židé. ${ }^{18}$ Cesty obchodování Ŕimanů a jejich prostředníků s čínským hedvábím lze dobře vystopovat podle nálezů rímských mincí. Suchozemská cesta vedla stř̌ední Asií po trase Hedvábné cesty. Námořní obchodní tepnu naznačují nálezy římských mincí na Srí Lance, v Indii, ale i ve Vietnamu. Řečtí mořeplavci se naučili využívat monzunových větrů $\mathrm{k}$ plavbě do Indického oceánu a stali se tak hlavními prostředníky námořního obchodu mezi Římskou říší a říší Chanů. Transport hedvábí z Číny byl doprovázen římskými vojenskými eskortami, at' už v egyptských prístavech u Rudého moře nebo po souši po Hedvábné cestě. ${ }^{19}$

Pliniův popis obchodování s Číňany tak, že zanechávali své zboží na opačném břehu a čekali, až si je kupující vyzvedne, lze vysvětlit také tak, že nebyli uvyklí přímému obchodu s barbary v soukromém prostoru. Lépe řečeno, byli zvyklí obchodovat v prostoru veřejném, který reguloval stát. Komentář k dějinám Číny Cuo-čuan vypovídá, že za bájné dynastie $\operatorname{Sia}^{20}$ na konci 3. tisíciletí př. Kr. měl její legendární panovník Božský rolník naučit lid směňovat výrobky: „Když slunce zářilo na poledni, shromáždil lid celé země a svezl zboží, a tak se konal trh."21 Potřeba výměnného obchodu rostla v Číně s rozvojem měst a řemesel, a proto dochází i k rozvoji obchodu, a to vnitřního i zahraničního. V době další bájné dynastie, dynastie Šang, ${ }^{22}$ se do obchodních vztahů zřejmě vložil stát a vládci státu Šang začali pravděpodobně obchod nejen regulovat, ale rozdělovat ho na obchod vnitřní a zahraniční. Název dynastie Šang (商) je dodnes v čínštině používán ve slovech a slovních spojeních označujících obchod, obchodníky a obchodování. Od doby Čou ${ }^{23}$ byl od obchodu vnitřního výrazně oddělen zahraniční obchod a stát začal k zahraničnímu obchodu vykonávat monopol. Pojem obchodního území byl v Číně umocněn za vlády dynastie Čchin, kdy byla odstraněna vnitřní cla. A tak chanský císař Wu-ti při budování své koncepce „obrana a obchod“, věren odkazu předků spojoval vnější obchod s rozšiřováním obchodního území pod kontrolou i ochranou státu.

Obě říše, římská i chanská, vedly v téže době boje o nová území. Římané rozšiřovali své impérium ve Středomoří, aby získali nové suroviny a přístup k obchodním cestám a další expanzi. Čínská tradice vztahu k západním oblastem měla obranný charakter. Svědčí o tom dodnes Velká čínská zed', kterou dal postavit čchinský krutovládný císař Čchin Š'-chuang-ti ${ }^{24}$ proti útočným sousedním kmenům, hlavně Siungnuům. ${ }^{25}$ Čchinové sice

\footnotetext{
17 Pomp. III, 50.

18 LIŠČ́́K, $c . d$.

19 ROSTOVZEV, M. Storia economica e sociale dell'Imperio Romano. Firenze: La Nuova Italia Editrice, 1946.

20 Bájná dynastie Sia měla v Číně vládnout asi v letech 2200-1760 př. Kr.

21 TOMÁŠEK, M. Dějiny čínského práva. Praha: Academia, 2004.

22 Legendami opředená dynastie Šang měla v Č́íně vládnout asi v letech 1760-1025 př. Kr.

23 Dynastie Čou vládla asi od roku 1025 př. Kr. do roku 771 př. Kr.

24 V letech 247-221 př. Kr. král čínského státu Čchin a první císař sjednocené Č́ny. Proslul tvrdým způsobem vlády, podporované drakonickými zákony a krutými tresty.

25 Siungnuové byl hunský kmen turkického či mongolského původu. Tyto původně kočovné kmeny periodicky napadaly severní hranice čínských států. Boje se Siungnuy provázely většinu období vlády dynastie
} 
na čas jejich útoky odrazili, ale po nástupu dynastie Chan jejich intenzita opět vzrůstala. Porazit Siungnuy byl právě úkol pro císaře Wu-tiho, který spojil s hledáním možností, jak posílit obchod s územími na západ od Číny. Správně totiž předpokládal, že obchodními vazbami s tradičními nepřáteli Siungnuů jednak posílí svoji obranu a jednak získá nové obchodní možnosti. Vojenské aktivity Chanů jsou tak propojeny s diplomacií, která je zase propojena s obchodem a obchodováním.

Patrně prvním čínským historicky doloženým obchodním diplomatem byl vyslanec císaře Wu-tiho jménem Čang Čchien. Asi v roce 138 př. Kr. se Čang Čchien vydal z pokynu svého císaře na západ, aniž věděl, kam dojde a zda se vůbec vrátí. K pomoci a ochraně mu dvůr poskytl stovku dobrovolníků. Po strastiplné cestě, při níž byl dvakrát zajat Siungnuy, se asi v roce 125 př. Kr. vrátil zpět na císařùv dvůr, aby informoval císaře, že na západě existují významné civilizace, s nimiž lze navazovat obchodní vztahy. Na své cestě vykonal v podstatě okruh, v němž na severu překročil Pamír a dostal se až do Fergany na území dnešního Uzbekistánu. Při návratu do hlavního města Chanské říše Čchang-anu se vydal přes severovýchodní okraj Tibetské náhorní plošiny, pohoří Čchi-lien-šan, čili přes dnešní hranici provincií Čching-chaj a Kan-su v severozápadní Číně. Právě tudy měla začas procházet Hedvábná cesta. Z diplomatického hlediska ovšem Čang Čchien př́liš úspěšný nebyl. Nepodařilo se mu přesvědčit potencionální spojence o společné akci proti Siungnuům, stejně jako se mu to nepodařilo ani při další výpravě z let 119-114 př. Kr. Ta byla vojensky o něco snazší, nebot' se mezitím Č́íňanům podařilo zatlačit Siungnuy dále na sever, a navíc trasu dobře znal. Během cesty vyslal též poselstva do Fergany, Samarkandu nebo severozápadní Indie. Jeho emisaři se dostali až ke břehům Kaspického moře. Po ukončení druhé výpravy Čang Čchien zemřel, dosáhnuv značného vlivu doma a renomé v cizině. Podle Dějin Chanů se rok po jeho smrti vrátili jeho vyslanci s dary a často i obyvateli zemí, které navštívili: „Poprvé státy severu tehdy vešly do styku s Chany. Byl to Čang Čchien, kdo razil cestu, a všichni, kdo tam pak šli jako vyslanci, zmiňovali jeho jméno jako záruku dobré víry u vnějších států, které pak k nim měly důvěru. "26 Čang Čchienovy mise jsou považovány na základ myšlenky otevř́t obchodní cestu mezi Čínou a Západem, která později dostala název Hedvábná cesta, protože po dlouhou dobu na ní jako zboží dominovalo čínské hedvábí.

\section{Hedvábná cesta}

Trasy Čang Čchienových expedic vzal císař Wu-ti za základ pro dvě trasy Hedvábné cesty, které se spojovaly na západním okraji pouště Taklamakan. Od 2. století př. Kr. vedla Hedvábná cesta z hlavního města Chanské říše Čchang-anu (dnešní Si-an) ve stř̌ední Číně přes Tun-chuang, Kašgar a Samarkand do Persie. Zde se štěpila na jižní trasu do Indie a na další trasy, vedoucí do dnešního Súru v Libanonu a do dnešní Antakye v Turecku. Její větev sahající do dnešní Sýrie pokračovala pak s využitím námořní cesty z dnešní syrské Antiochie až do egyptské Alexandrie. Velehory Pamíru dělily Hedvábnou cestu na východní a západní část. Na tomto místě budiž ovšem zdůrazněno, že název této dopravní tepny mezi Č́nou a střední Asií vznikl až ve druhé polovině 19. století. Autorství je připisováno

Chan, prakticky až do roku 87 po Kr. Siungnư̊m se dokonce podařilo získat kontrolu nad obchodem na hlavní trase Hedvábné cesty. 


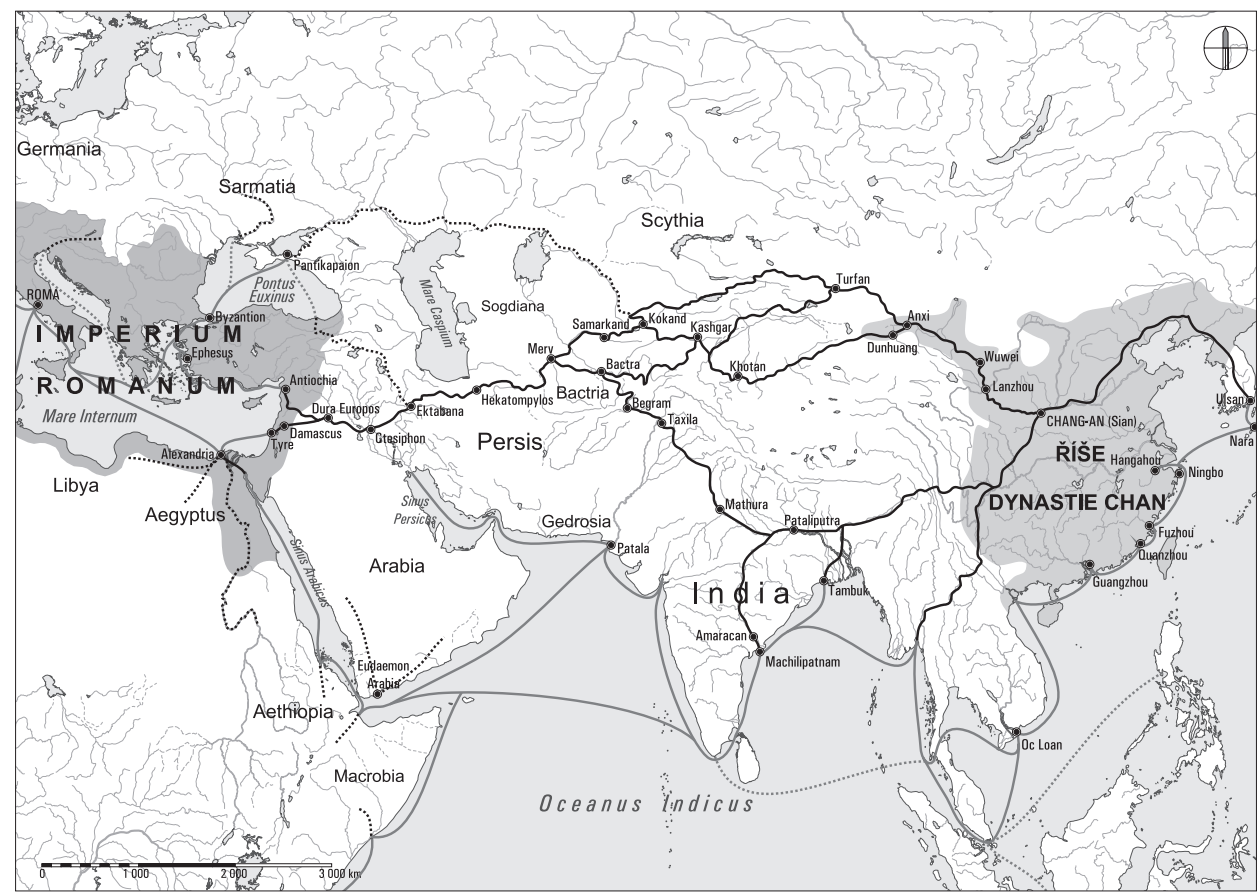

Trasa Hedvábné cesty ve 2. století př. Kr. Mapu překreslil Jaroslav Synek.

Ferdinandu Paulovi Wilhelmovi, baronovi von Richthofen, německému geografu a př́rodovědci, mimochodem strýci nejúspěšnějšího stíhače první světové války Manfreda von Richthofena přezdívaného Rudý baron. Ve svém díle China. Ergebnisse eigener Reisen und darauf gegründeter Studien z roku 1877 jako první použil pro celou sít' obchodních cest spojujících Čínu se Západem termínu Hedvábná cesta (Die Seidenstraße). ${ }^{27}$ Rychle se vžil, a to do té míry, že ho později převzali i sami Č́ínané doslovným překladem z němčiny jako $S^{\prime}$-čchou č lu (丝绸之路). Na počest Ferdinanda von Richthofena bylo výše zmíněné pohoří Čchi-lien-šan pojmenováno Evropany jako Richthofenovo pohoří.

Jestliže při své první misi měl Čang Čchien s sebou stovku bojovníků, pak při své druhé misi byl podle Dějin Chanů ,postaven do čela poselstva, jež čítalo tři sta mužů, z nichž každý měl dva koně, a dobytka a ovcí bylo na deset tisíc. Nesl s sebou zlato, drahocennosti a hedvábí nesmírné ceny. A byl s ním velký počet vyslanců nesoucích insignie, aby mohli být vysláni do sousedních států, umožní-li to cesty. “Č́nská poselstva na Západ byla vlastně diplomatickými misemi. V Dějinách Chanů se píše, že „každoročně bylo vysíláno maximálně deset a minimálně pět až šest poselstev. Poselstva se mohla na cestách navzájem vidět. Jediné poselstvo čítalo několik set lidí, bylo-li velké, nebo kolem sta, bylo-li malé. Ta, jež se vydávala na delší vzdálenosti, vracela se po osmi nebo devíti letech,

LIŠČÁK, $c . d$. 
na kratší vzdálenosti po několika letech. "28 Jakožto diplomatické mise byla poselstva vybavena četnými dary k navazování diplomatických styků. Ovšem Dějiny Chanů popisují, jak vyslanci nakládali s dary jako s vlastním majetkem a po cestě je levně rozprodávali k vlastnímu prospěchu. Mezi těmi, kdo přinášeli dary, nebyli totiž jen členové královské rodiny a šlechtici, ale i obchodníci, kteří chtěli vyměňovat zboží a obchodovat pod záminkou předložení darů. I tento v zásadě negativní prrípad svědčí o těsném propojení obchodu s veřejnou mocí. Obchodní mise totiž požívaly, řečeno naší terminologií, veřejnoprávní ochrany, byly chráněny vojenským doprovodem a platil v nich chanský právní režim. Např́klad roku 102 př. Kr. vyslal Wu-ti na západ vojenskou expedici čítající na 60000 vojáků, 100000 hlav dobytka, více než 30000 koní, po deseti tisících oslů a velbloudů a s množstvím služebnictva nesoucího osobní majetek členů expedice. Takové karavany na Hedvábné cestě nebyly nikterak výjimečné a lze je bez nadsázky označit za „,putující města“. Stát poskytoval svým obchodníkům vojenskou i právní ochranu. Na právní režim se vztahovala ustanovení zákona na ochranu dvora (jüe-kung lü 钱宫律), která upravovala režim bezpečnosti císařského dvora a paláce. ${ }^{29}$ Jestliže, jak již napsáno, se čínské mise nedovažovaly dále než na okraj pouště Taklamakan, končila i tam jejich vojenská ochrana a státní regulace. V těchto místech předávali Číňané své zboží prostředníkům k dalšímu obchodování.

Bylo by mylné dovozovat ze shora popsaného paradigmatu, že státem organizovaný čínský zahraniční obchod se soustřed'oval jen na suchozemské cesty a možnosti obchodu námořního ignoroval. Je pravdou, že až do 7. století čínský císařský dvưr námořní obchod aktivně nepodporoval, na druhé straně lze s úspěchem tvrdit, že Hedvábná cesta tak, jak se vytvořila $\mathrm{v}$ dobách dynastie Chan, měla i své námořní větve. Byl to opět císař Wu-ti, kdo si uvědomil význam také jižních cest především pro zajištění bezpečnosti země, ale i pro obchod. Jeho politika ,cesty na jih“ měla zajistit přístup k bohatým přístavům jižních moří za účelem obchodu a získávání dalších surovin. Byly vytipovány dvě zájmové oblasti: země jižních moří (nan-chaj 南海), čili oblast zhruba dnešní jihovýchodní Asie, a země západních moří (si-chaj 西海), tedy oblasti ležící na březích Indického oceánu. ${ }^{30}$ Pro aktivní obchod s nimi bylo ovšem třeba státního krytí, které mohlo být zajištěno toliko vojenskou akcí. Na cestě k jižním mořím dobyla Chanská říše v roce 111 př. Kr. podstatnou část vietnamského území, tehdejší stát Nam Viet, které se následně stalo na tisíc let součástí čínské říše. Na okupovaném území zavedli Č́iňané své právo, přesněji řečeno právo veřejné, tedy trestní a správní. Zavedli tam také čínské písmo. Hned v prvních letech okupace potlačili Č́ńnané dosavadní systém veřejné správy a zavedli vlastní strukturu státu Chan. Nejvyšší územně správní jednotkou se staly provincie (čínsky šeng 省, vietnamsky chau). V průběhu 1. století po Kr. se na vietnamském území vytvořily tři takové provincie. V jejich čele stanul čínský úředník, který řídil a kontroloval činnost devíti prefektur (čínsky čou 州, vietnamsky quan). Správu krajů vykonávali civilní úředníci za pomoci vojenských velitelů. Státní úředníci vládli na základě přímých př́íkazů čínského dvora a na jejich základě také kontrolovali veškerý obchod. Důležitým článkem tu byly vysoké daně do čínské pokladnice. Číňané však nezasahovali do místních soukromých obyčejů, včetně

HULSEWÉ, $c$. $d$.

TOMÁŠEK, Dějiny činského práva.

ANTONY, R. J. - SCHOTTENHAMMER, A. Beyond the Silk Roads - New Discourses on China's Role in East Asian Maritime History. Wiesbaden: Harrasowitz Verlag, 2017. 
těch obchodních. Ovšem obchod, zejména vnější postavili pod administrativní kontrolu svých úředníků.

Administrativní kontrola obyvatelstva byla rovněž vyznanou prevencí různých protičínských povstání a revolt, o něž v období „severní závislosti“ nebyla nouze. Nejúspěšnějšími bylo povstání sester Trungových v letech 40-43 po Kr. Obě sestry, dcery místních náčelníků, v reakci na uvěznění manžela jedné z nich místním čínským správcem, vyvolaly rebelii, $\mathrm{k}$ níž se záhy připojilo několik oblastí. Zaznamenáníhodná byla úloha žen $\mathrm{v}$ tomto povstání, které je nejen řídily, ale některé zastávaly i generálské funkce. ${ }^{31}$ Čínská vláda vyslala k potlačení povstání dvacetitisícové vojsko, které se vydalo jednak po souši, jednak po moři. V průběhu 1. století po Kr. postavili Chanové mohutné válečné lod'stvo, s nímž roku 42 vzbouřence porazili. Upevnili tak nejen svůj vliv ve Vietnamu, ale také přístup k novým trhům, hlavně s perlami. ${ }^{32}$ Povstání sester Trungových je spojováno s prŕístavem Ž'-nan a ten měl podle Ferdinanda von Richthofena otevř́ít námořní Hedvábnou cestu. Richthofen ho lokalizoval nedaleko dnešní Hanoje. Ležel tedy v nejjižnější komandérii kontrolované Číňany. Proto tudy mohl proudit státem regulovaný obchod. Tam také připlouvali první vyslanci rrímských císařu, kteří pak putovali k chanskému dvoru. Z Ž'-nanu vedly námořní cesty na Filipíny, do Indie, Srí Lanky a pak dále do Afriky. Na ty už Č́ńnané nevyplouvali. Zboží předali ve státem kontrolovaném př́istavu a jeho osudy dále přenechávali prostředníkům, a to včetně zboží určeného pro Římany. Archeologické nálezy ř́mských mincí, medailí a jiných předmětů, hlavně výrobků ze skla naopak dokládají, že Ž'-nan a Tonkin navštívili četní římští obchodníci. Byl prvním doloženým př́ístavem pod čínskou státní kontrolou a jeho právní režim později ovlivnil celý řetězec přístavů na východním pobřeží Číny. ${ }^{33}$

\section{Čínské hedvábí v Římě}

$\mathrm{S}$ hedvábím se Římané poprvé setkali v průběhu bitvy u Karrh roku 53 př. Kr., kde v boji s Parthy utrpěli těžkou porážku a kde padl i jejich vojevo̊dce Marcus Licinius Crassus. Historik Lucius Annæus Florus při popisu této bitvy uvádí, že „Římané byli ohromeni prapory Parthů, jež byly vyrobeny z lesknoucí se látky, kterou nikdy předtím neviděli““. Popisuje je jako auro sericeisque vexillis (prapory ze zlata a hedvábí). Zářily prý jako oheň a na Ř́many zapůsobily tak silně, že v hrůze utekli. ${ }^{34}$ Záhy poté, jak historicky doloženo ještě za vrcholné vlády Gaia Iulia Caesara, se hedvábí dostává jako obchodní komodita do Ríma. Už v roce 54 př. Kr. dal Caesar vybudovat proslulé náměstí Forum Iulium. Nedaleko v ulici Vicus Tuscus (Etruská třída) vznikl zvláštní trh hedvábím. Pro dámy se tam prodávaly průsvitné hedvábné tógy (toga vitrea), lehké oděvy zvané ,tkaný vánek“ (ventulus textilis) nebo ,plátěná mlha“ (nebula lintea). Lehké hedvábné oděvy si začali pořizovat i muži, což bylo bráno jako projev dekadentních mravů. Historik Cornelius Tacitus ve svých Letopisech (Annales) popisuje, jak byli už od počátku císařství kritizováni muži, kteří nosili hedvábný šat. ${ }^{35}$ Rovněž syn filozofa Senecy Lucius Annæus Seneca označuje

\footnotetext{
31 MiLlerovÁ, P. Vietnam. Praha: Libri, 2004.

32 TOMÁŠEK, M. Přehled dějin vietnamského práva. Praha: Právnická fakulta Univerzity Karlovy, 2008.

33 CRESPIGNY, c.d.

34 Flor. Epit. 65

35 Tac. Ann. II, 33.
} 
v polovině 1 . století po Kr. nošení hedvábných látek za „dekadentní rozmařilost“. ${ }^{36}$ Podle Tacita bylo roku 16 po Kr. v senátu usneseno, aby se „muži neoblékali do neslušného šatu z hedvábí'“. O několik let později roku 22 se obrátil osobním dopisem na senát císař Tiberius a požadoval, aby se dodržoval zákon proti přepychu. Zákon měl být podle něj aplikován i na ,šaty, jež si bez rozdílu oblékají muži i ženy“. ${ }^{37}$ Ve 3. století nicméně existují zmínky, že se do hedvábí odívali i římští císaři. Údajně mělo jít o císaře Heliogabala.

Zákony proti přepychu byly poměrně stálou součástí římského práva. Náš přední romanista Michal Skřejpek vidí jejich smysl nikoliv v tom, aby potíraly přepych obecně, nýbrž v omezování zbytečných a nadměrných nákladů. ${ }^{38}$ Odtud také původ jejich názvu z latinského sumere - vynaložit. Už od 5. století př. Kr. v Zákoně dvanácti tabulí regulovala desátá tabule různé výdaje na pořádání pohřbů. Kromě omezování výdajů na pohřby či hostiny se v jednotlivých vývojových stádiích mělo omezovat například držení drahých kovů nebo cenných předmětů. Zákon proti přepychu přijatý za Gaia Iulia Caesara v roce 46 př. Kr. (lex Iulia sumptuaria) zavedl speciální omezení týkající se používání purpuru, klenotů z perel, luxusních oděvů a užívání nosítek. Pro některé zvláštní příležitosti nebo pro některé osoby byly možné výjimky. Omezování přepychu v oblékání rozvinula norma přijatá roku 18 př. Kr. jako lex Iulia de vestitu et habitu, jíž bylo výslovně regulováno nošení hedvábí. Právě na ni se odvolával Tiberius ve shora zmíněném dopis senátu. Důvod k omezování luxusu v tomto i v jiných případech nebyl ovšem toliko prestižní. Pokud jde o jeho rozšíření na omezování nošení hedvábí, byl také ekonomický. Cena hedvábí se rychle zvyšovala, během pětadvaceti let vzrostla trojnásobně, přičemž byla vyvažována stř́brem. Císařovi ekonomičtí poradci v té souvislosti varovali, že by mohly být takto římské stř́ibrné rezervy brzy vyčerpány. Zákony proti přepychu existovaly mimochodem také v Č́ně, kde byly zavedeny už za dynastie Čchin.

\section{Rozhodné právo}

Ze srovnání ř́mského práva a soudobého čínského práva dynastie Chan mimo jiné vyplývá, že Ř́mané počítali se stykem s cizinci a jejich právo ius gentium na něj bylo zařízeno. ${ }^{39}$ Rímané byli přesvědčeni o dokonalosti svého práva, stejně jako Chanové uznávali jen ten svůj přirozený pořádek věcí za základ veškerého společenského dění, včetně obchodu. Své zboží zanechali cizím prostředníkům, převzali římské mince a o jeho další osudy, či právní režim se nezajímali. Nelze také ani spekulovat, že by se Rímané hlouběji zajímali o čínské obchodní obyčeje. Vše vybavovali jejich prostředníci (mercatores, negotiatores). Jestliže obchodování s Ř́many čínské právo nijak neovlivnilo, pak římské právo jeho důsledky řešilo. Konkrétně, pokud šlo o obchodování s hedvábím, či spíše o jeho důsledky. Chanové se naopak od cizinců izolovali, a proto nikterak neuvažovali, že by jejich právo existenci cizinců, či dokonce obchod s nimi mělo nějak zohledňovat. Obě říše nicméně počítaly s vojenskou ochranou svých obchodníků. Číňané, možná o něco více než Římané, chránili před cizinci své know-how. Tajemství bource morušového bylo v Číně př́ísně střeženo.

\footnotetext{
36 Sen ad Luc. III, 53.

37 Tac. Ann. II, 33.

38 SKŘEJPEK, M. Omezování přepychu v římském právu. Acta Universitatis Carolinae - Iuridica, 1997, č. 2, s. 7-17.

39 SKŘEJPEK, M. - BĚLOVSKÝ, P. - STLOUKALOVÁ, K. Cizinci, hranice a integrace v dějinách. Praha: Auditorium, 2016.
} 
Jeho vajíčka a semínka moruše měli z Číny propašovat do Cařihradu dva nestoriánští mniši na rozkaz východořímského (byzantského) císaře Justiniána I. kolem roku 550 v dutých bambusových holích. Naopak Rímané vyváželi do Číny své sklo bez zvláštních obav, že by jejich technologie mohla být nějakým způsobem kopírována.

Právní režim čínského zboží podléhal právu přepravce, v němž nejznámějším pramenem byl Rhodský zákon o vyhozeném (Lex Rhodia de iactu). Rhodos byl významným antickým přístavem a překladištěm čínského zboží, hlavně hedvábí. Je sám o sobě významným př́kladem přebírání práva helénistických států Římany. Zajišt’uje, aby v př́ípadě zboží vyhozeného do moře kvưli odlehčení lodi v př́ipadě hrozícího nebezpečí bylo příspěvkem všech nahrazeno to, co bylo dáno pro všechny. V př́padě čínského hedvábí bylo třeba posuzovat specifickou situaci, kdy do téže lodi navezlo více kupců své druhy zboží a za bouře bylo nutné některé zboží shodit do moře. Následně vznikla otázka, zda mají všichni odpovídat za věci vyhozené, tedy i ti, kteří vnesli takové zboží, jež lod' nezatížilo, například poměrně lehké hedvábí. Římští juristé se shodli, že všichni, kdo měli zájem na vyhození, musejí vzniklou škodu nést společně a nerozdílně. Poměrně je zavázán také vlastník lodi. Hodnotu vyhozeného bylo třeba rozdělit podle ceny věcí, přičemž hedvábí bylo považováno za předmět luxusu. Jelikož platilo, že je třeba provést ocenění nikoliv na tolik, za kolik bylo zboží koupeno, ale na tolik, zač může být prodáno, měla hodnota čínského hedvábí v takovém výpočtu značnou váhu. ${ }^{40}$ Římská právní doktrína uznávala Rhodský zákon za jediné právo na moři a vícekrát výslovně deklarovala, že s ním žádná část římského práva není v rozporu. Polský romanista Stanisław Płodzień považuje Rhodský zákon za významnou část římského ius gentium. ${ }^{41}$

Ř́mské právo se tedy s právem staročínským v obchodní oblasti míjely. Protnuly se možná jejich veřejnoprávní systémy. Na severozápadě provincie Kan-su byly archeology nalezeny ř́mské mince a přilbice s čínským nápisem. Čínský historik Pan Ku v souvislosti s bitvou u Li-čchien, která se odehrála právě v těchto místech roku 36 př. Kr. píše, že se jí měli účastnit i běloši. ${ }^{42}$ Dále se zmiňuje o bojové technice ,šupinové formace“, která nápadně připomíná rímskou bojovou ,želví formaci“. Město prý bylo chráněno dřevěnými palisádami známými z rrímské architektury. Americký historik Homer H. Dubbs a s ním i ruský antropolog a etnolog Lev Gumiljov spekulují, že po bitvě u Karrh měla upadnout do zajetí i asi desítka tisíc římských vojáků. ${ }^{43}$ Jejich technika údajně zaujala natolik, že byla využita spolu s římskými vojáky právě při bitvě u Li-čchien. Pokud tomu tak skutečně bylo, potvrdila by se domněnka, že Č́iňané převzali některé prvky římského vojenského práva, ovšem nikoliv z obdivu k římskému právu jako takovému, nýbrž z pragmatické potřeby využít účinnou vojenskou technologii.

Nad čínským vnitřním i vnějším obchodem se od nepaměti táhly dlouhé stíny státu. Č́inský stát obchodníky kontroloval, reguloval je, ale také jim poskytoval ochranu. Úředník stál nad obchodem také z jiného důvodu. Obchodníci byli v Číně vždy považováni

40 SKŘEJPEK, M. Digesta seu Pandectae. Tomus I. Liber I-XV. Fragmenta selecta. Digesta neboli Pandekty. Svazek I. Kniha I-XV. Vybrané části. Praha: Karolinum, 2015.

41 PŁODZIEŃ, S. Lex Rhodia de iactu. 2. vyd. Lublin: Wydawnictwo KUL, 2010.

42 HULSEWÉ, $c$. $d$.

43 DUBS, H. H. A Roman city in ancient China. Greece \& Rome, 1957, Vol. 4, No. 2. GUMILËV, L. N. KURKČI, A. I. Černaja legenda: Istoriko-psichologičeskij etjud. Chazar, 1989. 
za podřadnou kastu, kdežto úředník byl konfuciánský ušlechtilý člověk a ve společenské hierarchii stál o několik tř́id výše. Proto císař Wu-ti a jeho následovníci vysílali po Hedvábné cestě se svými obchodníky také ochranu a dohled, ale jen do určité vzdálenosti. Proto kontrolovali námořní obchod ve vybraných přístavech. Obchodovat mimo stíny státu se považovalo za nepatřičné, a proto tak k obchodování s čínským zbožím nastupovali prostředníci.

Jak bylo již napsáno, vytvořili Chanové dokonalý a kompaktní právní systém, který se stal základem dalšího vývoje čínského práva pro následující tisíciletí. Nejdůležitějšími prameny chanské kodifikace, využívané i pro regulaci obchodu, byly zákony (律 lü), i když tento termín lze podle chanského pojetí překládat dvojím způsobem. V širším smyslu označoval obecné zásady právní, či soubor právních norem, v užším smyslu se jednalo o obyčejný zákon. Dalším pramenem práva byla císařská nařízení (令 ling). Vzhledem $\mathrm{k}$ tomu, že podle chanského práva byl císař nadán mandátem nebes, bylo císařské nařízení pramenem práva nejvyšší právní síly. Císařská nařízení mohla rušit i měnit ustanovení zákonů. Toto pravidlo neplatilo ovšem bezvýjimečně. S ohledem na jiný konfuciánský princip, princip úcty $\mathrm{k}$ předkům, byla $\mathrm{v}$ kodexech ponechávána i ustanovení, která byla císařskými nařízeními zrušena nebo změněna. Platnost takových ustanovení byla sice pozastavena, ale tato skutečnost nijak nevylučovala možnost, že se k nim v budoucnu někdo vrátí jako k „odkazu předků““.44 Termín kche (科) označoval předpis, který určitým způsobem třídil právní skutečnosti. $\mathrm{V}$ době chanské byly kche součástí norem trestního práva, původně jako vysvětlující články k jednotlivým trestným činům. Později se staly samostatným pramenem práva. $V$ době pozdních Chan plnily úlohu jakéhosi prováděcího předpisu $\mathrm{k}$ trestním zákonům. Zcela novým přínosem chanské jurisprudence do systému pramenů práva byly soudní precedenty (判例 pchan-li), shromažd'ované ve sbírkách soudních precedentů. Když se začalo ukazovat, že psané právo není s to reagovat na všechny situace, které každodenní život přináší, justice si začala vytvářet precedenty, které per analogiam aplikovala v soudní praxi.

Historie Hedvábné cesty byla dlouhá a spletitá. Pochodovaly po ní karavany se zbožím, setkávaly se tu kultury i filozofie. Právě díky ní se do Číny začal šiřit buddhismus a pronikaly po ní myšlenky islámu. Střetávaly se na ní samozřejmě i právní kultury, ale ta čínská zůstávala po staletí vůči cizím vlivům více méně imunní. Je proto otázkou do budoucna, jak se čínské právo, také díky projektu Nové hedvábné cesty, dá cizími právními kulturami ovlivnit. 